\title{
The Bioethical Concept of Life for Life in Judaism, Catholicism, and Islam: Abortion When the Mother's Life is in Danger
}

\author{
Rhami Khorfan, BA; ${ }^{1}$ Aasim I. Padela, MD, MS2 \\ ${ }_{1}$ Wayne State University School of Medicine \\ ${ }^{2}$ Departments of General Internal Medicine and Emergency Medicine \\ University of Michigan
}

\begin{abstract}
Modern secular bioethics has focused on developing a set of universal principles to guide clinical decision making. However, this ignores the important role of religion in resolving bioethical questions. It is imperative that healthcare providers understand these belief systems in order to traverse value conflicts and provide the highest quality care to a diverse population. This paper focuses on the process of bioethical deliberation in Judaism, Catholicism, and Islam. Abortion is normatively prohibited in each faith and through examining how each ethical code allows for abortion when the mother's life is in peril due to the fetus, we highlight the value of unborn life in each faith. Orthodox Judaism uses the concept of rodef, or pursuer, to permit abortion in this scenario, Catholicism uses the moral concept of "double effect," while Islamic law cites the maqāsid, higher objectives of the law, to permit abortion in this scenario.
\end{abstract}

Key words: Bioethics, abortion, Judaism, Catholicism, Islam.

Introduction

$\mathrm{M}$ odern medical practice is becoming increasingly diverse. The various ethnic, racial, and religious identities within the patient population lead to a myriad of value systems being at play in the clinical realm. At times these value and cultural differences between the practitioner and the patient can lead to ethical challenges, and in order to find amicable solutions, understanding each party's moral values and ethical constructs is of utmost importance.

Modern medical ethics, in its secular form, has focused on the establishment of values and princi-

Correspondence should be directed to

Rhami Khorfan

5209 Warwick Woods Trail

Grand Blanc, MI 48439

e-mail:rkhorfan@gmail.com ples that can guide physician-patient interactions within this multicultural context. The most popular model is that expounded by Beauchamp and Childress, which promotes nonmaleficence, beneficence, respect for autonomy, and justice as its four guiding principles. ${ }^{1}$ However, religious beliefs do not fit easily within this four-principle model. As a result, various faith groups have tried to profess medical ethics based upon their own sacred law and ethical structure. ${ }^{2}$ This paper discusses the way that Orthodox Judaism, Catholicism, and Sunni Islam approach medical ethics and examines their stance on issues of dire necessity relating to abortion whereby the clinical context is deemed substantial enough to overturn the normative prohibition against abortion.

Judaism

Judaism refers to the religious system set forth by the Hebrew Scriptures of Ancient Israel (also 
known in Christianity as the old Testament) supplemented by the rabbinic formulations and commentaries of the first six centuries of the Common Era (such as the Mishna). Together the scripture and the rabbinic writings are called "the Torah," the former transmitted in writing and the latter initially in oral form and later written down by a rabbinic sage. ${ }^{3}$

The term "Torah" is used variably in Judaism and in a strict sense refers to the Five Books of Moses: Genesis, Exodus, Leviticus, Numbers and Deuteronomy (the Pentateuch), but is also used to refer to the entire corpus of Jewish religious teachings. ${ }^{4}$ For our purposes, the term "Torah" will denote the Hebrew scripture taken together with the rabbinic writings.

\section{Jewish Ethics and Halacha}

There are three primary streams in Jewish religious practice marked by their levels of adherence to the Pentateuch: Orthodox, Reform, and Conservative. The Orthodox movement is the oldest and most diverse form that follows a strict and literal interpretation of the Pentateuch as it holds it to be the exact word of God and subscribes to the belief that God's laws are immutable. 5 This paper draws mostly from the Orthodox movement's interpretation of Jewish law.

In Judaism bioethical inquiry is a subset of halacha (Jewish sacred law). As such it draws its principles from sacred texts and their commentaries, and utilizes an elaborate system of halachic reasoning. The three main sources of Jewish ethicolegal thinking are the Hebrew scriptures of ancient Israel, the Talmud, and the Responsa literature. The Hebrew Scriptures is the holy book of Judaism of which the Pentateuch holds the status of the highest source of law. ${ }^{6}$ Simultaneous to the written text, an oral tradition of interpretation and commentary was composed by rabbinic sages during the first six centuries of the Common Era. Eventually this tradition was written down around 200 C.E. and is known as the Mishna. ${ }^{3}$ The Mishna was amplified through further commentaries that came to be known as the Gemara (there are two: a Palestinian and a Babylonian). Together the Mishna and Gemara are known as the Talmud, which is the second source of law but whose influence on Jewish sacred law and moral codes is even greater than that of the Old Testament. ${ }^{6}$ The Talmud is not just a book of rulings; it is a transcript of legal debates through the centuries and contains a multiplicity of recorded positions on any particular subject. The third source of legal authority is the Responsa literature. ${ }^{7}$ These works are collections of opinions on contemporary matters as interpreted through the Hebrew Scripture and the Talmud. This literature spans centuries of thought and contains opinions of scholars from all over the world. In addition to these three main sources there are codifications of Jewish law that summarize the primary teachings, one of the most notable is the Mishne Torah, written by a noted 12th-century physician and scholar, Maimonides (Ibn Maymun).7,a

Ethical legal reasoning starts with extracting the primary data on the subject from the Talmud, likely in the form of rulings in particular cases, or arguments about the validity of such rulings. Next, a hypothesis is formulated as to the general principle that explains the collections of rulings. Lastly, through deductive logic the principle is applied to new circumstances that are not covered explicitly by earlier rulings. 6 This process is undertaken by a trained rabbi in response to a questioner. In practice, because there are multiple codifications and manuals of Jewish law, a rabbi might consult a particular manual for rulings rather than labor through halachic reasoning anew. This process of halachic reasoning has allowed Jewish law to be dynamic, addressing issues on the basis of circumstance and precedent while allowing for enduring applicability.

\section{Abortion}

The halacha puts great value on human life, and views every human life as having infinite worth. 9 However, the fetus is seen as a "prehuman" life rather than a full life. Only at birth are full rights given to the fetus. ${ }^{10}$ Although a fetus is not equal to a full human life, the halacha still endows this potential life with certain rights and it is considered generally inviolable.

It follows then that abortion in the halachic view is prohibited. Different sources give several reasons, but the ruling is largely based on the verse, "Whosoever sheddeth the blood of man in man, his blood shall be shed" (Genesis 9:6). Here, "man in man," is understood to be a fetus, and feticide is equated with murder. ${ }^{9}$

The exemption to this prohibition requires an immediate and compelling necessity. Most authors 
note that Jewish law permits an abortion when the mother's life is in peril. This danger to the mother's life does not necessarily have to be definitive; it can be a probable threat to the mother's life.10 This permission is based on an interpretation of the halachic term rodef, meaning pursuer. This concept allows someone to kill a thief that is breaking into one's house, because one may assume that the thief is armed and may kill him or her. The fetus is thus seen as a "pursuer," which is threatening the mother's life. This threat must be stopped, even if it means killing the pursuer. ${ }^{9}$

Jewish bioethicists have developed four categories of illnesses to differentiate between different levels of necessity. The first is "discomfort," including minor coughs and rashes. ${ }^{9}$ The next category, "minor illness," includes irritating coughs and headaches that are severe but not to the point of requiring bed rest. 9 Patients who "are severely but not fatally ill" and/or whose "limbs but not lives are in danger" comprise the third category. ${ }^{9}$ This category includes illness that confines patients to the bed or illnesses that require preventative treatment. Finally, "a potentially fatal condition" is the fourth category. ${ }^{9}$ For each of these categories, there are different restrictions on when and what type of normative prohibitions can be violated. These rulings range from no permitted violations for the first category, to all prohibitions being overturned for the fourth category.

Applying this four-category model to abortion leads to the same conclusion: that abortion of an unborn fetus is allowed if the mother's life is in danger. This is because if a woman's pregnancy is causing a "fatal" illness, the mother falls into the fourth category and everything must be done to save her life, including violating a command from the Torah. If this is not done, then whomever is responsible for the woman's health is guilty of murder, because it is a much graver offense than abortion, which is not considered murder by Jewish law.11

\section{Catholicism}

The Catholic Church is a federation of 24 churches that place authority in the pope regarding matters of faith and morality. The largest of these 24 churches is the Latin Church, also known as the Roman Catholic Church. The other 23 churches are known as "particular churches" or "Eastern Catholic
Churches." (Schweda, Phillip J (Chaplain, University of Michigan Hospital, Ann Arbor, MI). Conversation with authors. 2009-JUL-16. Unreferenced, see "Notes") The pope (the supreme pontiff or Roman pontiff) is the head of the Roman Catholic Church and is a quasi-absolute monarch who rules from the Vatican City, also known as the Holy See. He is elected by an elite group of bishops known as the College of Cardinals, whose members receive their position through appointment by the previous pope. There is also a papal court known as the Curia, which governs all matters of the church. The pope's authority stems from being the lineal successor to St. Peter and thereby is Jesus' representative on earth. Further augmenting his authority, the doctrine of papal infallibility allows the pope to define Catholic teachings in all spheres of life, but in practice this is rare. The other 23 particular churches have limited autonomy but are still responsible to the Curia. (Schweda. Conversation with authors. See "Notes")

Within the Catholic Church there exists an organized system of clergy of patriarchs, bishops, priests and deacons who minister to the needs of the church and its adherents.

\section{Catholic Moral Theology and Canon Law}

Canon law refers to the body of laws and regulations developed or adopted by Catholic Church for the government of the Catholic organizations and the faith community. Canon law is at times referred to as ecclesiastical law; however, the former includes legislation borrowed from Roman law as well as those made by the Church, while the latter encompasses only those laws authored by the Church.12 The sources of canon law are natural divine law and positive divine law (revelation). Both are contained in the scriptures and in tradition. Importantly, the New Testament of Jesus Christ is considered to abrogate most of the laws based in the Old Testament, save the Ten Commandments, and certain matrimonial regulations. ${ }^{12}$

The author of canon law is the church that, as described above, holds supreme authority in matters of faith and morals and is charged with setting up a society running according to divine (canon) law. The bishops and pope taken together are the active sources of canon law as they decree regulations through ecumenical councils. The pope holds the power to set law by himself and the power to abro- 
gate laws made by predecessors or by ecumenical councils. (Schweda. Conversation with authors. See "Notes")

Along with law, Catholic ethicists also deal with another field in debating ethical issues, moral theology.(Schweda. Conversation with authors. See "Notes") This is the theological study of what a human must do in order to gain the favor of God. It is defined and guided by natural ethics, Christian scripture, and the positive laws of the church. Catholic moral thought is a deductive process, starting from principles laid out in theology and applying it to cases through rational argumentation. We will see an example of this process in the discussion of abortion found below.

\section{Abortion}

The guiding principle in Catholic moral thought's dealings with abortion is the supremacy of the right to life. Catholic ethicists place the right to life above all else, because without life there can be no other good.13 We will begin discussing abortion in the Catholic tradition with a summary given by renowned ethicist Daniel Callahan:

1. God alone is the Lord of life.

2. Human beings do not have the right to take lives of other (innocent) human beings.

3. Human life begins at the moment of conception.

4. Abortion, at whatever the stage of development of the conceptus, is the taking of innocent human life. The conclusion follows: Abortion is wrong." 14

The distinguishing feature of Catholic ethics when dealing with abortion is the equality, from the very beginning, of the lives of the fetus and the mother. Pope Pius XII said, "Even the unborn child is a human being in the same degree and by the same title as its mother."14 This is distinct from the Islamic and Jewish view of fetal life as potential or prehuman life. Understanding this equality helps in understanding the seemingly strict stance on abortion taken by Catholic moral ethicists.

Necessity can only be used to override the Catholic prohibition of abortion if the fetus is not directly harmed. Catholic ethicists justify this type of abortion based on the principle of double effect, which states "An action that has both a good and a bad effect may be performed if the good effect accomplished is greater than the evil effect." 14 Applying this to abortion, if a mother has a fatal medical condition that can be treated through surgery, only such surgery that does not directly harm the fetus is permissible. For example, if the mother has appendicitis an operation is permissible because the operation does not involve directly harming the fetus to save the mother's life. Another example would be the case of an ectopic pregnancy when the embryo implants into the fallopian tube and a continued pregnancy would lead to rupture and the possibility of maternal and fetal death. In this scenario surgical removal of the fallopian tube is permitted even though it would cause the death of the growing embryo, here seen as a potential life of infinite value, because the process is indirect. In contrast to the indirect death of the fetus, procedures such as crushing the skull of the fetus are seen as direct killing and prohibited even if this is the only means to save the mother's life. ${ }^{14}$ The principle of double effect thus follows the rationale that the intended result of the procedure that indirectly harms the fetus is saving the mother's life, which is good, and the death of the fetus is an indirect evil. Thus the good result outweighs the bad result and the procedure is allowed.14 However in the direct case the moral impermissibility stems from directly ending one life, that of the fetus, in order to save another, the mother's. Some Catholic moral philosophers explicitly state that in this case two natural deaths are better than one murder.

\section{Islam}

The Arabic word "Islam" carries meanings of "submission (to God)" and "to enter into the peace (of God)." Thus Islam is more properly defined as an action rather than a fixed entity. The term, however, has come to represent the monotheistic tradition of faith and practice that holds Muhammad ibn Abdullah aلd 7 th century Mecca to be the final prophet from a long lineage of prophets including Noah, Abraham, Jesus and Moses (PBUT). Hence "Islam" represents a cumulative tradition spanning 14 centuries, which the Muslims, those who carry out the action of submitting to God, developed and adapted in diverse ways to varied times, places and contexts. Yet, despite the diversity of time and place, the Muslims of the world refer to a singular universe of meaning elaborated on and rooted in a certain number of fundamental principles. In succinct form, the root meanings of the word "Islam" imply 
Muslims believe that by sincerely and totally submitting to God inwardly and in external action, one can attain true peace within one's self and manifest it outwardly in this life, and will find everlasting peace in the hereafter.

\section{Shari'ah and Medical Ethics}

Islamic medical ethics as a cohesive discipline is still in its formative stages. ${ }^{15}$ Within Islamic medical ethics literature there are two dominant genres. The first is adab literature; writings related to character ethics both in the professional and personal realms. The other genre is more concerned with Islamic ethics as rooted in Islamic sacred law, or shari ${ }^{-1}$. These writings aim at expounding the moral values attached to using certain medical technologies and interventions based on Islamic legal and ethical principles. ${ }^{15}$ Indeed, as is the case with the Jewish halacha, the shari $a$ encompasses all aspects of life and thus its scholars use sharī'a-based principles and formal techniques to find Islamic perspectives on all spheres of human activity from modes of banking to government.

Islamic sharī $a$ has two dimensions, the first being the physical corpus of legal rulings, precedents, and statutes, and the second being the intellectual and moral code of Islam. ${ }^{15}$ In Islamic teaching the shari $a$ is the source of Muslim existence as it represents "the correct path of action as determined by God." The absence of a state authority enforcing the sharī $a$ in totality has relegated the shari' $a$ to a more theoretical sphere better thought of as "the collective ethical subconscious" of the Muslim community. ${ }^{16}$ For this reason, Muslim patients and ethicists may refer to the sharī $a$ when making decisions about abortion, end-of-life care, and other biomedical issues.

Islamic legal reasoning and thought is very different from Catholic reasoning. Instead of reasoning from a general principle to specific situations, scholars of Islamic law take a normative example from the Qur'an or Sunnah and try to apply its spirit or their understanding of the reasons behind it to new situations.

Through the course of Islamic history, different methodologies and legal theories developed to reach a ruling from the Qur'an and Sunnah, some of these systems became extinct and others were codified and organized into schools of law. The four Sunni schools that have survived to modern times -- Hanafi, Mālikī, Shāfi'ì, and Hanbalī -- are all considered valid and orthodox interpretations. While it is beyond the scope of this paper to delve into the legal frameworks of these Sunni schools, all four schools accept four sources of law: the Qur'an, the hadith, ijma $\bar{a}^{\prime}$ and qiyās. ${ }^{17}$ The Qur'an is held to be the literal word of God and "is a source of knowledge in the way that the entire corpus of legal precedent is for the common law tradition; not as much as an index of possible rulings (rather) as a quarry in which the astute inquirer can hope to find the building blocks for a morally valid, and therefore, true system of ethics." 18 The hadith encompasses collections of reports of sayings, actions and silent affirmations of the Prophet

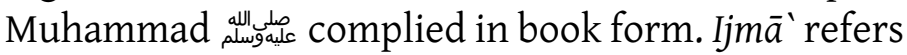
to consensus agreement about the moral and/or legal assessment of an act or practice. Its scope can include how a particular hadith or Qur'anic injunction should be applied and interpreted, as well as a record of agreement on an issue that may not be explicitly covered by the two material sources. Differences exist within the different schools of law. The dominant opinion is that ijm $\bar{a}$ ' is the agreement of Muslim-learned persons at a time, after the death of the Prophet allevalle on a "legal matter."19 Qiyās is juristic reasoning by analogy.19 In application it stands for applying a certain ruling from an established case if the predisposing conditions, which led to the ruling in the first case, apply to a second case. Thus the process of applying qiyas through inductive and deductive reasoning is strikingly similar to halachic reasoning in Judaism.

\section{Abortion}

Islamic scholars have identified five essential goals, or maqāșid, of the sharī $a$. These are protection of religion, life, intellect, lineage, and property. A dire necessity (darūra) that threatens one of these five values may be enough to overturn any normative prohibition based on the principle al-darūrāt tubih al-mahzūuāt. ${ }^{21}$ In medical issues, the necessity is often left to be defined by Muslim physicians who can be trusted in both medical expertise and religiosity. 22

Abortion in Islam is understood first as an interference with God's role as the ultimate owner and decider of life and death. Human life is valued because it is made by God.21 As mentioned earlier, 
Islamic legal reasoning can lead to varying opinions on one issue, and abortion is no exception. The four schools differ in the moral culpability and legal permissibility of abortion before the $120^{\text {th }}$ day of pregnancy; whether it is prohibited categorically or simply morally discouraged and what conditions allow for its undertaking. ${ }^{22,23}$ However, there is ijma among the Muslim scholars that abortion is prohibited after 120 days. ${ }^{22}$ This is based on a hadith of the

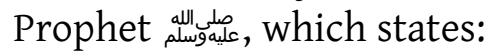

The Prophet of God told us - and he is the one who speaks the truth and evokes belief "Each of you is gathered in his mother's womb for forty days; then [he is] a clot of blood for the same period; then he is a clump of flesh for the same period ...Then the spirit is breathed into it..." 22

Muslim scholars agree that after the moment when the soul is "breathed into it," also known as the moment of ensoulment, the fetus is considered a human and gains almost full rights according to Islamic law and abortion is prohibited. The one necessity that overrides the prohibition of abortion after 120 days is when the mother's life is at stake. This is because abortion is a darūra to save the mother's life, one of the five maqāsid. At this point, the mother's life is protected at the value of the potential life of the fetus. ${ }^{22}$ The specific definition of what constitutes a potential-versus-actual harm to the life of the mother is left unspoken and subject to circumstantial consideration. All of the four major schools of law allow for the sacrificing of an unborn child even after 120 days of pregnancy to preserve the mother's life, and they put this decision in the hands of a competent Muslim physician.

\section{Conclusion}

Religion is a very important source of ethical values and principles for many patients and physicians. In an increasingly multicultural environment, clinicians come in contact with many religious ideals, some of which may be alien to them. This cursory look at three of the most prominent religious ethical systems may help clinicians to understand and interact with different value systems, thus improving the quality of their care. Abortion is one example of an ethical question with significant religious implica- tions, and a look at how each religion views the issue of taking one life to save another provides a useful illustration of their bioethical deliberation. Jewish halacha applies the concept of a rodef to allow abortion if the physician believes the fetus is endangering the mother's life. Catholic moral theology values the sanctity of life above all else, and therefore only allows abortion through the concept of "double effect" when abortion is an indirect consequence of a necessary procedure to save the mother's life. Islamic sharī' $a$ views protecting life as one of the five maqāsid, or higher objectives of the law, and therefore allows abortion to save the mother's life through the means of the principle of necessity allowing the prohibited (al-ḍrūrāt tubị al mahzūrāt), even after 120 days of pregnancy. Through this examination of abortion in each religion, we see one instance in which one life can be taken in order to save another and gain insight into the ethicolegal processes that were developed by each faith community to deal with the cases of life versus life.

\section{Notes}

The authors interviewed Philip J , a chaplain at the University of Michigan Hospital, Ann Arbor, MI, on 2009-JUL-16. He reviewed a late draft of this article and permitted JIMA to publish the citation to his communication in this article.

\section{Acknowledgments}

We would like to thank Rabbi Sara Adler of the University of Michigan Medical Center Spiritual Services, Rabbi Rod Glogower of the University of Michigan Hillel, and Reverend Phillip Schweda of the Diocese of Lansing for contributing their time and expertise to help guide our research.

\section{References}

1. Beauchamp TL, Childress JF. Principles of Biomedical Ethics. 4th ed. New York: Oxford University Press; 1994.

2. Ilkilic I. Bioethical conflicts between Muslim patients and German physicians and the principles of biomedical ethics. Med Law. 2002;21:243-56. PubMed PMID: 12184605

3. Neusner J, Chilton B, Graham W. Three faiths, one God: the formative faith and practice of Judaism, Christianity and Islam. Boston: Brill Academic Publishers; 2002. 
4. Torah.

Wikipedia.org. http://en.wikipedia.org/wiki/Torah Accessed 2009Jul-7.

5. Lewis JA. Jewish perspectives on pregnancy and childbearing. MCN Am J Matern Child Nurs. 2003;28:306-12. http://doi.org/g67

6. Breitowitz Y. How a rabbi decides a medical halacha issue. Conference on Jewish Medical Ethics. San Francisco, CA, 1996.

7. Goldsand G, Rosenberg ZR, Gordon M. Bioethics for clinicians: 22. Jewish bioethics. CMAJ. 2001;164:21922. PubMed PMID:11332319

8. Raddawi HM. Moses Maimonides (Musa ibn Maymun), a Jewish philosopher, theologian and physician: his life and works, an Islamic perspective. J Islam Med Assoc. 2006;38:23-8. http://dx.doi.org/10.5915/38-1-6274

9. Rosner F. Medicine and Jewish law. Northvale, NJ: Jason Aronson Inc.; 1990.

10. Halperin M, Fink D, Glick S. Jewish medical ethics. Volume 2. Jerusalem: Schlesinger Institute for Medical-Halachic Research; 2006.

11. Feldman DM. Health and medicine in the Jewish tradition. New York: The Crossroad Publishing Company; 1986.

12. Boudinhon A. Canon Law. The Catholic encyclopedia. New York: Robert Appleton Company; 1910.

13. Channer JH. Abortion and the sanctity of human life. Exeter, UK: The Paternoster Press; 1985.

14. Batchelor E. Abortion: the moral issues. New York: The Pilgrim Press; 1982.

15. Siddiqui A. Ethics in Islam: key concepts and contemporary challenges. J Moral Education. 1997;26:423-31.http://doi.org/g7c

16. van Bommel A. Medical ethics from the Muslim perspective. Acta Neurochir Suppl. 1999;74:17-27.

17. Padela AI. Medical ethics in religious traditions: a study of Judaism, Catholicism and Islam. J Islam Med Assoc 2006;38:106-17. http://dx.doi.org/10.5915/383-5245

18. Burton J. The collection of the Qur'an. London: Cambridge University Press, 1977.

19. Yacoub A. The fiqh of medicine. London: Ta-Ha Publishers Ltd.; 2001.

20. Kamali MH. Principles of Islamic jurisprudence. Cambridge: The Islamic Texts Society; 2003.

21. Brockopp JE. Islamic ethics of life: abortion, war, and euthanasia. Columbia: University of South Carolina Press; 2003.

22. Albar MA. An Islamic view on contraception and abortion. J Islam Med Assoc. 1989;21:79-81. http://dx.doi.org/10.5915/21-2-5527

23. IMANA Ethics Committee. Islamic medical ethics: The IMANA perspective. J Islam Med Assoc. 2005;37:33-42.http://dx.doi.org/10.5915/37-1-5528 